\title{
ДОСЛІДЖЕННЯ ЗДАТНОСТІ ДО СХЕМАТИЗАЦІї ЗДОБУВАЧІВ СТУПЕНЯ ДОКТОРА ФІЛОСОФІЇ (Ph.D.) ЯК МЕХАНІЗМУ ЇХ ПРОФЕСІЙНОГО МИСЛЕННЯ ТА МИСЛЕКОМУНІКАЦІї
}

\author{
Тетяна Гура \\ доктор психологічних наук, професор, \\ проректор з наукової роботи та міжнародної діяльності \\ Комунальний заклад «Запорізький обласний інститут післядипломної педагогічної освіти» \\ Запорізької обласної ради \\ 69035, м. Запоріжжя, вул. Незалежної України, 57-А \\ tatianagura16@gmail.com, http://orcid.org/0000-0002-4869-1360 \\ Олександр Гура \\ доктор педагогічних наук, професор, \\ проректор з навчальної та науково-педагогічної роботи \\ Запорізький національний університет \\ 69600, м. Запоріжжя, вул Жуковського, 66 \\ guru.olexandr@gmail.com, http://orcid.org/0000-0001-6720-2481
}

\begin{abstract}
Анотація
Статтю присвячено дослідженню здатності до схематизації здобувачів ступеня доктора філософії (Ph.D.) як механізму їх професійного мислення і мислекомунікації. Проаналізовано основні положення сучасної психологічної науки щодо розуміння сутності схематизації, як інструменту мислення i комунікації, засобу спільного проєктування i розвитку миследіяльності, а здатності до схематизації - як провідної професійної якості науковця, що має формуватися на етапі його професійної підготовки. Методи дослідження: теоретичні (аналіз: теоретичний, термінологічний; узагальнення, систематизація, класифікація); емпіричні (методи діагностики, адаптовані до завдань дослідження - самооцінювання, опитування, тестування); математичної статистики (метод середніх величин, кореляційного аналізу за допомогою IBM SPSS Statistics v.23). За результатами проведеного емпіричного дослідження визначено, що більшість здобувачів ступеня доктора філософії, які взяли участь у діагностиці, мають недостатній рівень знань (на рівні інтуїтивного знання) щодо сутності схем, усвідомлення їх місця серед інших методів візуалізації інформації, а також типів та принципів побудови, що унеможливлює актуалізацію їх здатності до схематизації як усвідомленої, відрефлексованої. Крім того, більшість здобувачів ступеня доктора філософії мають недостатній рівень розвитку уміння схематизації як об'єктів, так і процесів, порушують їх родо-видову організацію, існуючі правила символічної, графічної презентації. Попри це, оцінюють рівень розвитку власних умінь переважно на середньому та високому рівнях і кожен третій з них має низький рівень індивідуальної актуалізованості парціальної рефлексії діяльності, що забезпечує осмислення, оцінку їх миследіяльності й мислекомунікації. Встановлено, що актуальним завданням вітчизняної вищої освіти $\epsilon$ цілеспрямований розвиток здатності до схематизації здобувачів ступеня доктора філософії, що забезпечується реалізацією у змісті освітньо-наукових програм таких принципів, як:
\end{abstract}


забезпечення усвідомленості сутності схематизації, вбудованості в існуючий досвід, вербалізації, колективної миследіяльності, актуалізації різнорівневої рефлексії та мисленнєвої діяльності, поступового ускладнення побудованих схем, єдності конструктів, згорнутості інформації, етапності схематизаційного руху.

Ключові слова: схематизація, схема, мисленнєва діяльність, здобувачі ступеня доктора філософії (Ph.D.), наукова діяльність.

\section{Вступ}

Успішність комунікації як однієї з провідних сфер життєдіяльності кожної людини значною мірою залежить не лише і не стільки від ㄲï вміння вести діалог, як від рівня розуміння його смислу. Здебільшого, як засвідчує практика, зміст спілкування, що базується на певних знакових і лексичних формах (мова, жести, міміка тощо), спотворюється на рівні суб'єктивного розуміння/усвідомлення тексту або ситуації взаємодії загалом. Відбувається складна взаємодія між знаннями і конструкціями значень: «зміст знання якимось чином визначає структуру смислу, що виникає, і ту нову площину змісту, яка ій відповідає» (Щедровицький, 2014). Відтак, постає актуальною проблема зіставлення спілкування i мислення, яка на сьогодні знайшла своє часткове вирішення в контексті системомиследіяльнісного підходу (Громико, 2018; Акопова, Глазунова \& Громико, 2020; Дубровський, 2011; Щедровицький, 2012 та ін.) при дослідженні мислекомунікації особливого рівня мислення, яке відбувається завдяки оперуванню знаннями, що існують у формі понять, знаків, у процесі діалогу, тобто у комунікативній формі; та який існує за законами комунікації та діалогу.

Аналіз результатів попередніх досліджень (Гура, 2015; Gura O. \& Gura Т., 2020; Gura T., Gura O. \& Chernikova, 2020) надає підстави стверджувати, що розвиток мислекомунікативної сфери залежить від сукупності механізмів, які забезпечують успішність iii функціонування, базовими серед яких можна визначити вербалізацію, об’єктивізацію, нормування та рефлексію. Найбільш ефективним засобом їх активізації є схематизація, яка 3 одного боку, дає змогу структурувати мисленнєву діяльність, вибудувати іiі відповідно до стратегій спілкування, а з іншого, - об’єктивізувати їі результати, перевести їх на чуттєвонаочний рівень, тобто візуалізувати.

Поняття «схема», «схематизація» вже давно увійшли в науковий обіг саме в контексті дослідження когнітивної та комунікативної сфер людини. Так, зокрема, схема розуміється: як структура, що перероблює та впорядковує інформацію (Abbot-Smith \& Tomasello, 2006), організовує мисленнєву діяльність людини, допомагає розкрити сутнісні характеристики тексту, інформації, які передає інший (Акопова, Глазунова \& Громико, 2020, Holmes \& Wolff, 2010, 2013); засіб спільного проєктування та розвитку миследіяльності (Тюков, 2007; Kalinina O. \& Kalinina N., 2019). Виходячи із своїх функцій, схема не є семіотичним, епістемічним, символічним утворенням. Вона $\epsilon$ абсолютно особливим утворенням, що, поперше, визначає умови мислимості, рефлексивності, можливості розуміння, по-друге, чуттєвості і дієвості та, по-третє, - включення активності, взаємодії (Щедровицький, 2014). Кожна людина має певні схематизовані уявлення про типову ситуацію - фрейми, в яких $є$ узагальнена основа - «каркас», що відтворює стійкі характеристики ситуації та «вузли», чутливі до динаміки життя і здатні наповнитися новими даними. У сучасній психологічній науці вже не потрібно доводити, що поки предмет і діяльність не схематизовані та не прорисовані, вони не існують для нашого мислення та розуміння, існує лише можливість їх 
існування (Громико, 2018; Гура, 2020; Тюков, 2007; Дубровський, 2011; Щедровицький, 2014). Для ефективної миследіяльності й мислекомунікації важливе використання людиною різних типів схем: 1) об'єктно-онтологічних, що презентують сутнісні характеристики об'єкта / процесу, показують яким він є; 2) процесуальних або схем дії - презентують рух, процес, перетворення та 3) організаційно-діяльнісних або методологічних, що організують мисленнєву діяльність суб'єкта, визначають рух у певному реально-символічному просторі.

3 позиції функціонування, схеми мають і певні характерні особливості, зокрема: можуть бути різними за типами; є цілісними і автономними утвореннями (мають особливу графіку, яка не є суто семіотичним утворенням; не обов'язково пов'язані з іншими схемами, контекстами) (Kalinina O. \& Kalinina N., 2019); при необхідності заповнюються додатковою інформацією; є загальними унормованими, але також містять конкретний індивідуальний досвід, який відповідає шаблону; вони керують процесом вирішення проблем, спрямовують його (Marshall, 2012) та ін.

Схематизація $€$ складним процесом, що здійснюється за певними етапами та спрямований на створення знакової форми мислення або об'єктивного змісту; свідомим рефлексивним виокремленням людиною суттєвих, першочергових елементів об'єкта, процесу, а також самої себе як суб'єкта мисленнєвої діяльності як в індивідуальному, так і колективному контексті (мислекомунікації). Вона забезпечує формування розвиненої свідомості, рівень розвитку якої визначається характером рефлексії (предметної, діяльнісної та методологічної), що у свою чергу детермінується здатністю у внутрішньому плані свідомості заміщати всі композиції комунікації та програвати переходи з позиції на позицію. Ця здатність формується лише у процесі навчання читанню схем, їх малювання та інтерпретації (Тюков, 2007; Abbot-Smith \& Tomasello, 2006; Clark, 2016; Paivio, 2014).

Особливого значення здатність до схематизації має для науковців, адже саме наукова діяльність за своєю сутністю як найскладніша, метасистемна, спрямована на вирішення проблем найвищого рівня невизначеності (Бохан, Алексеева, Шаболовская, Морева \& Кузнецова, 2014), вимагає найвищого рівня організації як їх мисленнєвої діяльності загалом (на рівні методологічного мислення (Гура, 2020), так і мислекомунікації зокрема, що забезпечує презентацію ідей у науковому співтоваристві, здійснення проєктної діяльності (Gura O. \& Meniailo, 2019) тощо. Саме наукова діяльність здійснюється іiі суб’єктом за етапами мисленнєвого пошуку, як рух думки від виявлення протиріччя, формулювання проблеми, визначення мети наукового дослідження та побудови моделі досліджуваного об’єкта / процесу (проєктувальний етап) до безпосередньої перевірки побудованої наукової гіпотези (технологічний етап) і процедури самооцінки, оцінки й презентації результатів дослідження (рефлексивний етап). Схематизація забезпечує зв'язок мислення і дії, є засобом спільного проєктування та розвитку миследіяльності, рефлексивним нормативно-проєктним баченням майбутнього кроку діяльності (Щедровицький, 2014); вона забезпечує створення науковцями моделі досліджуваного об’єкта/процесу i, таким чином об'єктивізує, опредмечує, унормовує їх мисленнєву діяльність та переводить ії на методологічний рівень. Усе вищезазначене ставить особливі вимоги до підготовки докторів філософії (Ph.D.) у закладах вищої освіти України, одним із показників якості якої має бути спрямованість на цілеспрямований розвиток у майбутніх науковців здатності до схематизації.

Мета дослідження полягала в емпіричному виявленні здатності до схематизації здобувачів ступеня доктора філософії (Ph.D.) як механізму їх професійної мислекомунікації. Завданнями дослідження $є:$ 1) наукове обгрунтування методики визначення здатності до 
схематизації здобувачів ступеня доктора філософії (Ph.D.); 2) емпіричне вивчення рівня розвиненості здатності до схематизації здобувачів ступеня доктора філософіï (Ph.D.); 3) з'ясування особливостей прояву здатності до схематизації здобувачів ступеня доктора філософії.

\section{Методи дослідження}

Для дослідження здатності до схематизації здобувачів ступеня доктора філософії був використаний комплекс діагностичних методів, серед яких: 1) авторська методика «Схематизація», що спрямована на виявлення: а) когнітивної складової - знань щодо сутності схем, усвідомлення їх місця серед інших методів візуалізації інформації, а також типів та принципів побудови; та б) операційної складової - умінь схематизувати об'єкти явища (професійну компетентність сучасного доктора філософії/кандидата наук), процеси i, зокрема, власну миследіяльність (власну наукову діяльність); в) самоцінної складової самооцінку вмінь візуалізувати інформацію, створювати схеми явищ i процесів, презентувати їх. Показниками рівнів розвиненості здатності до схематизації, відповідно до авторської методики, були визначені такі: усвідомленість сутності поняття «схема», іiі характерних ознак; розробленість усіх типів схем (об’єктно-онтологічної, процесуальної, організаційно-діяльнісної); обсяг і повнота знань (концептів), розкритих у схемі, що подані у вигляді іiі родо-видової організації; генералізованість інформації про об’єкт і процес у схемі; універсальність графіки схеми, що забезпечує ії зрозумілість, презентованість для інших; складність графічного способу побудови схеми (проста блокова схема або діаграма Ісікави, цикл Демінга та ін.); адекватність самооцінки рівня розвиненості вмінь візуалізувати інформацію, створювати схеми явищ і процесів, презентувати їх.

Методологічним підгрунтям розробленої методики $є$ положення інтегративномиследіяльнісного підходу (Гура, 2020) про те, що схематизація як особливий процес не $\epsilon$ результатом неповного, поверхового сприйняття суб'єктом об'єкта, забуванням несуттєвих деталей предмету або ситуації, але $\epsilon$ багатоетапним процесом, що спрямований на створення знакової форми об'єктивізації власного мислення, є свідомим рефлексивним виокремленням суттєвих, первинних аспектів об’єкта, процесу, а також самого себе як суб'єкта мисленнєвої діяльності.

Верифікація авторської методики за параметром валідності здійснювалась на основі методик 16PF Кетела і резистентності до невизначеності PCRS (Personal change readiness survey), у перекладі та адаптації М.О. Бажанова, Г.Л. Бардієр; 2) Тест рефлексії діяльності (Шадриков \& Кургінян, 2015), що є валідізованою методикою і дає змогу визначити міру індивідуальної актуалізованості парціальної рефлексії діяльності, яка, в свою чергу, забезпечує об'єктивізацію миследіяльності майбутніх науковців, успішність процесу їх мислекомунікації.

Емпіричне дослідження було здійснено у грудні 2019 року за участю 32 здобувачів ступеня доктора філософії (Ph.D.), які навчалися за різними освітньо-науковими програмами у Запорізькому національному університеті впродовж 2-4 років. Серед них: $81 \%$ жінок та 19\% чоловіків віком від 23 до 45 років більшості освітніх галузей (філологія - 22\%, історія $12,5 \%$, прикладна фізика, професійна освіта, менеджмент - по 9\%, біологія та психологія по 6,25\%, будівництво та інженерія математика, комп'ютерні науки, журналістика, право, соціальна робота і маркетинг - по 3,125\%), з різними рівнями готовності дисертаційної роботи за їх власною оцінкою (від 5\% з 100\% обсягу дисертації - 16\% здобувачів і до 20\% зі 
$100 \%$ - 56,25\% здобувачів до більше $20 \%$ - 9,375\% здобувачів). Причому максимальний рівень готовності дисертаційної роботи за оцінкою здобувачів був визначений на рівні 40\% зі $100 \%$ можливих (3,125\% майбутніх науковців).

Для статистичної обробки отриманих даних було використано сучасні інформаційні технології (IBM SPSS Statistics v.23).

\section{Результати та дискусії}

За результатами проведеного дослідження отримано дані, що свідчать про таке. Поперше, більшість здобувачів ступеня доктора філософії мають недостатній рівень знань про сутність схем, усвідомлення їх місця серед інших методів візуалізації інформації, а також типів та принципів побудови. Так, лише $12,5 \%$ респондентів надали повне, коректне визначення поняття «схема» через такі конструкти, як «форма візуалізації інформації про об'єкт завдяки графічним символам», «графічне зображення ключових елементів явища / процесу», або «графічно поданий план діяльності», 50\% здобувачів взагалі не змогли надати власне визначення цього поняття. Крім того, 72\% здобувачів не змогли сформулювати визначення такого поняття, як «модель», а 56,25\% - «проєкт», 37,5\% ототожнюють зміст цих термінологічних конструктів. Недостатній рівень усвідомлення майбутніми науковцями сутності явища схеми та схематизації виявляється й у домінуванні у них інтуїтивних знань щодо типів схем та принципів їх побудови, ототожненні схеми 3 «коротким викладенням матеріалу», «планом» та «алгоритмом дій».

По-друге, більшість здобувачів ступеня доктора філософії мають недостатній рівень розвитку вміння схематизації як об'єктів, так і процесів. Так, 56,25\% респондентів не змогли створити схему професійної компетентності сучасного доктора філософії / кандидата наук, зафіксувавши лише текстові вимоги, не використовуючи графічних компонентів; 31,25\% порушили родо-видову організацію явища професійної компетентності. I лише 12,5\% здобувачів створили схему, що репрезентує для інших їх наукову позицію у доступний для розуміння спосіб, використавши просту блочну організацію. Щодо схематизації процесу власної наукової діяльності, то були отримані схожі дані: 43,75\% здобувачів ступеня доктора філософії не змогли створити відповідну схему, 31,25\% - замість схеми наукової діяльності презентували компоненти дисертаційної роботи в текстовому форматі, 25\% - подали окремі, непов'язані один з одним елементи, що лише частково розкрили етапи наукової діяльності.

По-третє, кожен другий із здобувачів ступеня доктора філософії оцінює рівень розвиненості власних умінь щодо візуалізації інформації як середній (за шкалою від 1 до 10 балів), 28,125\% - як початковий та 18,75 - як високий. Власні уміння створювати схеми явищ та процесів, презентувати їх іншим майбутніми науковцями були оцінені переважно на середньому $(40,625 \%)$ та високому $(37,5 \%)$ рівнях.

По-четверте, індивідуальна актуалізованість парціальної рефлексії діяльності як провідний механізм, що забезпечує об'єктивізацію миследіяльності майбутніх науковців, успішність процесу їх мислекомунікації, виявляється у більшості 3 них на низькому i середньому рівні: 1) за загальним показником рефлексії діяльності - 59,375\%, низький рівень був виявлений у $31,25 \%$ і високий - у 9,375\%; 2) за ступенем інформаційної міри прояву рефлексії інформаційної основи їх діяльності - 68,75\%, низький рівень був виявлений у 31,25\% респондентів; 3) за критерієм рефлексії мотивації та цілепокладання діяльності 65,625\%, низький рівень був виявлений у 31,25\% та високий - у 3,125\%; 4) за шкалою 
рефлексії прийняття рішення та здійснення діяльності - 53,125\%, низький рівень виявлений у $37,5 \%$ та високий - у 9,375\%.

Проведений статистичний аналіз отриманих даних засвідчив про наявність: значущої стійкої позитивної кореляції між рівнем самооцінки здобувачами ступеня доктора філософії рівнів розвиненості їх умінь візуалізації й схематизації $(\mathrm{r}=0,852)$; а також значущої стійкої негативної кореляції між загальним показником рефлексії діяльності та рівнем самооцінки їх умінь візуалізації інформації $(\mathrm{r}=-0,51)$ та схематизації $(\mathrm{r}=-0,57)$.

Отже, наше цілком логічне припущення про те, що здобувачі ступеня доктора філософії, магістри, які цілеспрямовано вступили в аспірантуру для входження у наукову спільноту, для здійснення наукового пошуку з розв'язання комплексних професійних проблем, отримання нових наукових знань, формально поданих у дисертаційній роботі, будуть мати розвинену здатність до схематизації, не підтвердилося. Отримані результати дослідження свідчать i про те, що навчання в аспірантурі, проходження етапів дисертаційного дослідження не забезпечують формування когнітивної та операційної складових здатності майбутніх науковців до схематизації.

Відтак, перед вітчизняною вищої освітою постає актуальне завдання щодо цілеспрямованого розвитку здатності до схематизації здобувачів ступеня доктора філософії в процесі опанування ними освітньо-наукових програм. Це досягається, на нашу думку, завдяки реалізації таких спеціальних принципів як-то: забезпечення усвідомленості сутності схематизації (формування у здобувачів спеціальних знань щодо сутності схем і схематизації, етапів та інструментів схематизації, правил, критеріїв оцінки тощо); вбудованості в існуючий досвід (нові вміння схематизації мають накладатися на вже існуючі у здобувачів уміння, досвід); вербалізації (обов'язкового проговорення, інтерпретації не лише розроблених схем, але й власної миследіяльності); колективної миследіяльності (групової побудови та інтерпретації схем, що забезпечує відповідну професійну мислекомунікацію); актуалізації різнорівневої рефлексії (предметної, діяльнісної й методологічної); поступового ускладнення побудованих схем відповідно до їх різних рівнів (від об'єктно-онтологічних до організаційно-діяльнісних) і мисленнєвої діяльності; єдності конструктів (єдиних правил використання графічних елементів); згорнутості інформації у схемі, іiі символічності та узагальненості; етапності схематизаційного руху (від інтерпретації створених схем іншими до створення власних схем, роботи на схемі, їі коригування до культурної, соціальної та професійної легітимізації схеми, а також рефлексивної оцінки власної мисленнєвої діяльності). Зазначені принципи можуть бути реалізованими у різних організаційних формах - спецкурсах, організаційно-діяльнісних іграх, рефлепрактикумах, тренінгах тощо та мати наскрізний характер.

\section{Висновки}

Результати проведеного дослідження засвідчують, що незважаючи на усвідомлення сучасною психологічною наукою важливості схематизації, як базового механізму миследіяльності та мислекомунікації людини, а здатності до схематизації - як провідної властивості науковця, більшість здобувачів ступеня доктора філософії (Ph.D.) мають недостатній рівень іiі розвитку. Отримані емпіричні дані засвідчили про:

- домінування в них інтуїтивних знань щодо типів схем і принципів їх побудови, етапів схематизації та їх значення для наукової діяльності; 
- недостатній рівень розвитку вмінь із схематизації різних типів схем - як об'єктних, так і процесуальних і методологічних, зокрема - власної наукової діяльності;

- недостатній рівень актуалізованості їх парціальної рефлексії діяльності, що забезпечує об'єктивізацію їх миследіяльності.

Гіпотеза авторів про те, що здобувачі ступеня доктора філософії, які цілеспрямовано вступили в аспірантуру для здійснення наукового пошуку і навчання за освітньо-науковою програмою будуть мати розвинену здатність до схематизації, не підтвердилася.

Здійснене наукове обгрунтування діагностичного комплексу здатності до схематизації, що містив авторську методику «Схематизація» і Тест рефлексії діяльності, дає змогу проводити моніторинг і визначати шляхи активізації професійної мислекомунікації і миследіяльності здобувачів ступеня доктора філософії (Ph.D.). Зазначене ставить особливі вимоги до змісту, форм і методів вітчизняної підготовки майбутніх учених.

Перспективи подальших досліджень убачаються у вивченні особливостей здатності майбутніх науковців до схематизації різних освітніх галузей, виявленні ії динаміки на різних етапах освітньо-наукової підготовки, а також науковому обгрунтуванні схематизаційного мислення як особливого феномена наукової миследіяльності.

\section{Література}

1. Акопова, Э.С., Глазунова, О.И., \& Громыко, Ю.В. (2020). Диагностическая методика оценки способностей к проектированию деятельности в групповой работе «Периметр». Психологическая наука и образование, 25(2), 5-18. doi: 10.17759/pse.2020250201

2. Бохан, Т.Г., Алексеева, Л.Ф., Шаболовская, М.В., Морева, С.А., \& Кузнецова, Т.М. (2014). Ресурсы и дефициты психологической готовности к научно-исследовательской деятельности. Психологическая наука и образование, 6(2), 198-208. Режим доступа: http://psyedu.ru/journal/2014/2/Bohan_et_al.phtml

3. Громыко, Ю.В. (2018). К проблеме создания общенародной школы будущего: синтез предметного и проектного образования. Психологическая наука и образование, 23(1), 93105.

4. Гура, Т.Є. (2015). Схематизація: ресурси для розвитку професійного мислення фахівців у системі вищої та післядипломної освіти. Технології розвитку інтелекту, 1(9). Режим доступу: http://nbuv.gov.ua/UJRN/tri_2015_1_9_9.

5. Дубровский, В.Я. (2011). Очерки по общей теории деятельности. Москва : ННФ «Институт развития им. Г.П. Щедровицкого».

6. Тюков, А.А. (2007). Схемь и схематизащия. Режим доступу: https://www.fondgp.ru/old/lib/conferences/2007/notes/5.html

7. Шадриков, В.Д., \& Кургинян, С.С. (2015). Парциальность рефлексии деятельности. Акмеология, 64(2), 68-83.

8. Щедровицкий, Г.П. (2014). Оргуправленческое мышление: идеология, методология, технология (курс лекиий). Москва : Изд-во Студии Артемия Лебедева.

9. Abbot-Smith, K., \& Tomasello, M. (2006). Exemplar-learning and schematization in a usagebased account of syntactic acquisition1. The Linguistic Review, 23(3), 275-290. doi: 10.1515/TLR.2006.011

10. Clark, J. (2016). Dual Coding Theory and Education. Educational Psychology Review, 3(3), 149-210. doi: 10.1007/BF01320076 
11. Gura, O., \& Gura, T. (2020). The study of practical psychologists' professional thinking: the authors' integrative and thinking-activity approach. Всеукраїнський науково-практичний журнал "Директор иколи, лічею, гімназї̈. Спеціальний тематичний випуск «Міжнародні Челпанівські психолого-педагогічні читання» 2(2), 130-142.

12. Gura, O., \& Meniailo, V. (2019). Building a Project Culture through Research and Innovation Training of Future PhDs in Ukraine. International Journal of Education and Practice, 7(4), 377-390. https://doi.org/10.18488/journal.61.2019.74.377.390

13. Gura, T., Gura, O., \& Chernikova, L. (2020). Research on metacognitive skills of software testers: a problem statement. ICTERI 2020 Proceedings, II. Retrieved from http://ceurws.org/Vol-2732/20200607.pdf

14. Holmes, K.J, \& Wolff, P. (2010). Simulation from schematics: dorsal stream processing and the perception of implied motion. In R. Catrambone \& S. Ohlsson (Eds.) Proceedings of the 32nd annual conference of the cognitive science society. Cognitive Science Society, 2704-2709.

15. Holmes, K.J, \& Wolff, P. (2013). Spatial language and the psychological reality of schematization. Cognitive Processing, 14(2), 205-208. doi: 10.1007/s10339-013-0545-5

16. Kalinina, O., \& Kalinina, N. (2019). Schematization methods of project thinking. Journal of mechanics of continua and mathematical sciences. Inst mechanics continua \& mathematical sciences. doi: 10.26782/jmcms.2019.03.00050

17. Marshall, S.P. (2012). Schema-Based Problem Solving. In: Seel N.M. (eds) Encyclopedia of the Sciences of Learning. Boston, MA : Springer. doi: 10.1007/978-1-4419-1428-6_262

18. Paivio, A. (2014). Intelligence, dual coding theory, and the brain. Intelligence 47, 141-158. doi: 10.1016/j.intell.2014.09.002

\section{References}

1. Akopova, E.S., Glazunova, O.I., \& Gromyiko, Yu.V. (2020). Diagnosticheskaya metodika otsenki sposobnostey $\mathrm{k}$ proektirovaniyu deyatelnosti $\mathrm{v}$ gruppovoy rabote «Perimetr». [Diagnostic technique for assessing the ability to design activities in group work "Perimeter"]. Psihologicheskaya nauka i obrazovanie - Psychological Science and Education. 25(2), 5-18. doi: 10.17759/pse.2020250201 [in Russian].

2. Bohan, T.G., Alekseeva, L.F., Shabolovskaya, M.V., Moreva, S.A., \& Kuznetsova, T.M. (2014). Resursyi i defitsityi psihologicheskoy gotovnosti k nauchno-issledovatelskoy deyatelnosti. [Resources and deficiencies of psychological readiness for research activities]. Psihologicheskaya nauka i obrazovanie - Psychological Science and Education, 6(2), 198-208. Retrieved from http://psyedu.ru/journal/2014/2/Bohan_et_al.phtml [in Russian].

3. Gromyko, Ju.V. (2018). K probleme sozdanija obshhenarodnoj shkoly budushhego: sintez predmetnogo i proektnogo obrazovanija. [On the problem of creating a public school of the future: the synthesis of subject and project education]. Psihologicheskaja nauka i obrazovanie Psychological Science and Education, 23(1), 93-105 [in Russian].

4. Hura, T.Ie. (2015). Skhematyzatsiia: resursy dlia rozvytku profesiinoho myslennia fakhivtsiv u systemi vyshchoi ta pisliadyplomnoi osvity. [Schematization: resources for the development of professional thinking of specialists in the system of higher and postgraduate education]. Tekhnolohii rozvytku intelektu - Technologies of intelligence development, 1(9). Retrieved from http://nbuv.gov.ua/UJRN/tri_2015_1_9_9 [in Ukrainian].

5. Dubrovskij, V.Ja. (2011). Ocherki po obshhej teorii dejatel'nosti [Essays on the general theory of activity]. Moscow : NNF "Institut razvitija im. G.P. Shhedrovickogo" [in Russian]. 
6. Tjukov, A.A. (2007). Shemy i shematizacija. [Schemes and schematization]. Retrieved from https://www.fondgp.ru/old/lib/conferences/2007/notes/5.html [in Ukrainian].

7. Shadrikov, V.D., \& Kurginjan, S.S. (2015). Parcial'nost' refleksii dejatel'nosti. [Partial reflection of activity]. Akmeologiya - Acmeology, 64(2), 68-83 [in Russian].

8. Shhedrovickij, G.P. (2014). Orgupravlencheskoe myshlenie: ideologija, metodologija, tehnologija (kurs lekcij). [Organizational and managerial thinking: ideology, methodology, technology (course of lectures)]. Moscow : Izd-vo Studii Artemija Lebedeva [in Russian].

9. Abbot-Smith, K., \& Tomasello, M. (2006). Exemplar-learning and schematization in a usagebased account of syntactic acquisition1. The Linguistic Review, 23(3), 275-290. doi: 10.1515/TLR.2006.011

10. Clark, J. (2016). Dual Coding Theory and Education. Educational Psychology Review, 3(3), 149-210. doi: 10.1007/BF01320076

11. Gura, O., \& Gura, T. (2020). The study of practical psychologists' professional thinking: the authors' integrative and thinking-activity approach. Vseukrainskyi naukovo-praktychnyi zhurnal «Dyrektor shkoly, litseiu, himnazii». Spetsialnyi tematychnyi vypusk «Mizhnarodni Chelpanivski psykholoho-pedahohichni chytannia»-All-Ukrainian scientific-practical magazine "Director of school, lyceum, gymnasium". Special thematic issue "International Chelpanovsky psychological and pedagogical readings", 2(2), 130-142.

12. Gura, O., \& Meniailo, V. (2019). Building a Project Culture through Research and Innovation Training of Future PhDs in Ukraine. International Journal of Education and Practice, 7(4), 377-390. https://doi.org/10.18488/journal.61.2019.74.377.390

13. Gura, T., Gura, O., \& Chernikova, L. (2020). Research on metacognitive skills of software testers: a problem statement. ICTERI 2020 Proceedings, II. Retrieved from http://ceurws.org/Vol-2732/20200607.pdf

14. Holmes, K.J, \& Wolff, P. (2010). Simulation from schematics: dorsal stream processing and the perception of implied motion. In R. Catrambone \& S. Ohlsson (Eds.) Proceedings of the 32nd annual conference of the cognitive science society. Cognitive Science Society, 2704-2709.

15. Holmes, K.J, \& Wolff, P. (2013). Spatial language and the psychological reality of schematization. Cognitive Processing, 14(2), 205-208. doi: 10.1007/s10339-013-0545-5

16. Kalinina, O., \& Kalinina, N. (2019). Schematization methods of project thinking. Journal of mechanics of continua and mathematical sciences. Inst mechanics continua \& mathematical sciences. doi: 10.26782/jmcms.2019.03.00050

17. Marshall, S.P. (2012). Schema-Based Problem Solving. In: Seel N.M. (eds) Encyclopedia of the Sciences of Learning. Boston, MA : Springer. doi: 10.1007/978-1-4419-1428-6_262

18. Paivio, A. (2014). Intelligence, dual coding theory, and the brain. Intelligence 47, 141-158. doi: $10.1016 /$ j.intell.2014.09.002 


\title{
RESEARCH OF THE SCHEMATIZATION ABILITY OF PH. DS AS A MECHANISM OF THEIR PROFESSIONAL THINKING AND THOUGHT COMMUNICATION
}

\section{Tetiana Gura}

Doctor of Sciences in Psychology, Professor,

vice-rector for research and international work

Communal institution «Zaporizhzhya Regional Institute of Postgraduate Pedagogical Education» of Zaporizhzhya Regional Council

57-A, Independent Ukraine Str., Zaporizhzhya, Ukraine, 69035

tatianagura16@gmail.com, http://orcid.org/0000-0002-4869-1360

\author{
Oleksandr Gura, \\ Doctor of Sciences in Pedagogy, Professor, \\ vice-rector for educational and scientific-pedagogical work \\ Zaporizhzhya National University, \\ 66, Zhukovsky Str., Zaporizhzhya, Ukraine, 69600 \\ guru.olexandr@gmail.com, http://orcid.org/0000-0001-6720-2481
}

\begin{abstract}
The article is devoted to the study of the schematization ability of candidates for the degree of Doctor of Philosophy (Ph.D.) as a mechanism of their professional thinking and thought communication. It gives an analysis of the main provisions of modern psychological science on understanding the essence of schematization as a tool of professional thinking and thought communication, and the ability of schematization as a leading professional quality of a scientist which should be formed at the stage of his professional training. Research methods: theoretical (analysis: theoretical, terminological; generalization, systematization, classification); empirical (diagnostic methods adapted to research tasks: survey, testing, self-assessment); mathematical statistics (method of averages, correlation analysis using IBM SPSS Statistics v.23).

According to the results of an empirical research, most Ph.D. candidates who took part in the diagnosis have insufficient knowledge (at the level of intuitive knowledge) about the essence of schemes, awareness of their place among other methods of visualization, as well as types and principles of construction, which makes it impossible to characterize their ability to schematize as conscious, reflected. Moreover, most candidates for the degree of Doctor of Philosophy have an insufficient level of the ability to schematize both objects and processes, violate their generic organization, the existing rules of symbolic, graphic presentation. On the other hand, they assess the level of development of their own skills mainly at intermediate and high levels and every third of them has a low level of individual relevance of partial reflection of activities, which provides understanding, evaluation of their thinking process and communication. It is established that the urgent task of domestic higher education is the purposeful development of the ability of schematization in candidates for the degree of Doctor of Philosophy, which can be provided by the implementation in the content of educational and scientific programs such principles as: awareness of the essence of schematization, integration into existing experience. and mental activity, the gradual complication of the constructed schemes, the unity of constructs, the convolution of information, the stages of the schematic movement.
\end{abstract}

Keywords: schematization, scheme, mental activity, candidates for the degree of Doctor of Philosophy (Ph.D.), scientific activity. 